\title{
Торопец: градостроительная структура как летопись, запечатленная в генетических частях
}

\author{
Н.О.Кудрявцева, Москва \\ Л.И.Кубецкая, ЦНИИП Минстроя России, Москва
}

В статье представлено исследование процесса формирования градостроительной структуры Торопца: от «городища кривичей» к Кремлю, к Посаду и до границ современного города; анализируются особенности перемещения Посада, церквей, сложившихся в течение значительных временных эпох в устойчивую пространственно-композиционную систему. Существующие и поныне территории - древнее городище город кривичей, Красный остров, бывший Детинец, нынешняя площадь - древний торг, да и весь город в исторических границах начала XX века - составляют большую часть современной территории Торопца. В исследовании подтверждается неизменность начертания главной артерии юг-север, сложившейся при зарождении поселения, которая соединяет сохранившиеся в структуре генетические части, как бы нанизанные на историческую ось времени «север-юг». Авторы подробно останавливаются на особенностях расположения архитектурных ансамблей в структуре города, редчайших образцах сохранившейся застройки в стиле классицизм середины XVIII века; освещаются торопецкие традиции храмового зодчества: всё это формирует впечатляющие архитектурно-художественные образы и виды города, являющиеся отражением богатства историко-культурного наследия России.

Ключевые слова: градостроительная структура, пространственно-композиционная система, типология, стилистика торопецких церквей, историко-генетическая структура, национальная идентичность.

Toropets: Urban Structure as a Chronicle Depicted in Genetic Parts

\section{N.0.Kudryavtseva, Moscow}

L.I.Kubetskaya, TsNIIP Minstroy of Russia, Moscow

The article presents a study of the formation of Toropets urban structure: from "Krivichi settlement" to the Kremlin, to Posad and the borders of the modern city; analyzes the peculiarities of the movement of Posad, churches, formed during significant time epochs in a stable spatial-compositional system. The territories that still exist - the ancient settlement - the town of Krivichi, Red Island, former Dytynets, the current square - the ancient marketplace, and the whole town within the historical boundaries of the early 20th century - make up a large part of the modern Toropets territory. The study confirms the invariability of the outline of the main south-north artery, formed at the origin of the settlement, which connects the genetic parts preserved in the structure as if threaded on the historical axis of time "north-south". The authors dwell upon the peculiarities of architectural ensembleslocation in the structure of the town, the rarest specimens of classicism style buildings of the early-mid 18th century, the Toropets traditions of church architecture are represented: all these make impressive architectural and artistic images and views of the town which reflect the richness of Russian historical and cultural heritage.

Keywords: urban structure, spatial-compositional system, typology, stylistics of Toropets churches, historical-genetic structure, national identity.

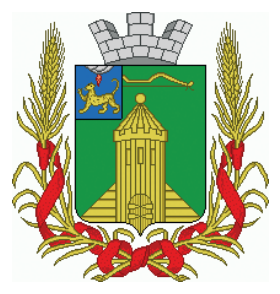

Вы подъезжаете к Tоропиу и вам ещё за несколько вёрст бросаются в глаза сияющие купола разноцветных массивных каменных церквей, слепившихся в одну кучу и отвлекающих ваш взор от всего другого.

И. Щукин

Tоропец - лучший город всей Новгородской губернии. Я. Сиверс, губернатор Новгородской губернии (1768)

Город с его региональными и планировочными особенностями, своеобразной архитектурой храмов, общественных зданий, типами рядовой застройки создаёт особое зрительное впечатление и остаётся в памяти благодаря этим образам. Так, Владимир с его Успенским и Дмитровским соборами в градостроительном представлении в значительной степени связывается с древними частями «Печернего», «Нового» и «Ветчаного» городов, сформировавшимися в период XI-XIII веков (от Владимира Мономаха до Всеволода Андреевича). Очевидно, что градостроительная структура является хранителем исторической памяти и представляет собой летопись, разворачивающуюся в генетических частях города.

Город Торопец Тверской области - феномен культуры, хранитель различных по характеру национальных ценностей, сохраняющихся в градостроительном наследии. Градостроительная структура и композиция порождают в исторической перспективе визуальный образ города, который рос от Малого Городища к Большому, к Кремлю, к Посаду. Генетические 
части своим расположением, соответствующим временной последовательности сложения частей (Городище, Детинец, Посад, слободы), как бы нанизаны на одну временную ось, это позволяет ощутить историческую память.

Храмовые ансамбли, вписанные в планировку, разновременная, разностилевая застройка, являются частью культурного наследия и рассказывают о духовных и культурных традициях и архитектурно-художественном мастерстве. Уникальность Торопца анализируется по трём срезам соответствии с этапами формирования: градостроительная структура - композиция - традиция.

Торопец - один из и тридцати древнейших городов России, упоминаемых в летописях - расположен на западе Валдайской возвышенности в 263-х километрах к западу от Твери на реке Торопе.

По официальным летописным источникам город Торопец известен с 1074 года и впервые упоминается в летописи в связи с постригом в монахи Киево-Печерского монастыря торопецкого купца Исаакия. Этот год принято считать годом основания города [1].

B XVIII веке первый историк Торопца священник Пётр Иродионов свидетельствовал и описал «нарочито окопанные и положением отличные горы», которые назывались «поклонными». На них, как предполагают, находились древние кумирницы, памятники языческого времени.

Название города «Торопец» - вторичное, первое - «Кривитеск», («Кривичь» или «Кривиг») принадлежало первому поселению кривичей VII-VIII веков. Земли торопецкие по обеим берегам реки Торопы, по верхнему течению реки Западной Двины были чрезвычайно привлекательны для расселения. Преобладали островной и полуостровной типы. В летописи говорится, что здесь проживали угро-финские племена. С конца VIII века в них вливаются племена славян кривичей, которые постепенно вытеснили угро-финские племена или растворили их в своей массе. B IX веке здесь на Светлицком озере возникло поселение викингов.

В летописях отмечается, что в IX-X века через торопецкую землю пролегали международные торговые пути. Уже тогда, видимо, существовало поселение, жители которого занимались

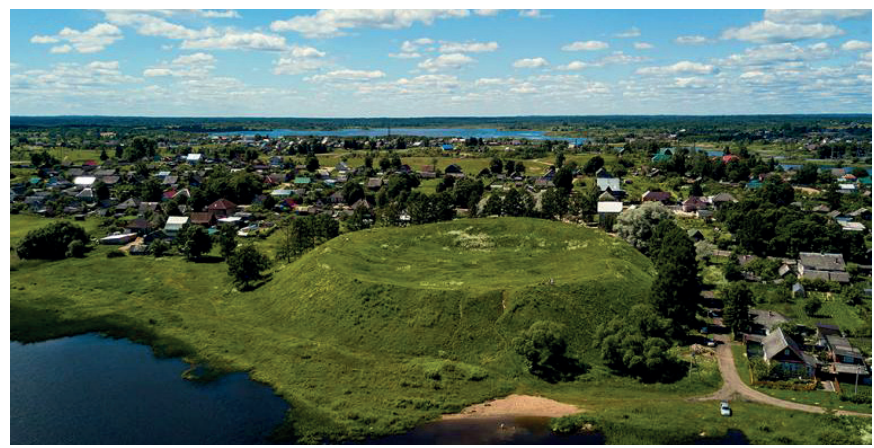

Рис. 1. Малое Торопецкое городище (Кривит), представляющее собой поселение первой половины XI век (фото из открытых источников сети Интернет) транзитной торговлей, а роль его была связана с контролем над торговыми путями и дорогами. В XI веке, когда полоцкий князь захватил земли и закрыл для Киева систему волоков из Днепра в Ловать, появился другой 30-километровый участок из реки Желны в реку Сережу, Торопец приобрёл большое значение как остановочный и административный пункт.

B IX-X веках Торопец - «город порубежный и торговый», будучи в составе Киевской Руси, занимал исключительно выгодное положение на великом водном торговом пути, получившем в древности название «из варяг в греки» и служил опорным центром участка торгового пути, соединявшего Новгород с Киевом, а также в целом Русь и страны Северной Европы со странами Средиземноморья и Востоком, что позволяло ему контролировать трансконтинентальную связь. Город упоминается как среднее по величине поселение, впоследствии ставшее известным феодальным городом.

XII-XIV века - следующий этап исторического становления, связанный с периодом вхождения в состав Смоленского княжества. Благодаря своему стратегически важному положению между Новгородской, Полоцкой, Южно-Русской, Суздальской областями, Торопецкое княжество в 1167 году при МстиславеХрабром обособляется от Смоленского княжества и становится самостоятельным [2]. Оно играло роль посредника в торговле и политическом отношении между соседствующими с ним областями.

Литовские набеги на Торопецкое княжество начинаются с 1206 года и повторяются довольно часто. В результате при Ольгерде Торопец окончательно покорен Литвою. Три века территория была подвластна княжеству Литовскому, пока в 1499 году Торопец не был возвращён русскими войсками и по перемирию, заключённому в 1503 году, официально закреплён в составе Московского княжества.

C XII по XIV век Торопец был главным городом всей северной трети Смоленского княжества. Тогда же на Малом городище сформировался укреплённый центр Торопца. В начале XII века вокруг крепости сооружены ров и вал, по гребню которого шла стена - передовая система обороны (рис. 1) [3].

Первоначально поселение не имело характера города. Территория составляла 0,7 га, в нём насчитывалось 80 домов, а население не превышало 240-300 человек. В XII веке проведено укрепление Городища, что отвечало важным задачам обороны того времени и свидетельствовало о геополитическом значении Торопца как важного опорного центра Смоленского княжества. Малое городище было самым укреплённым местом и имело форму трапеции со срезанными и круглыми углами. Его размеры были 95х60 м. Высота вала над уровнем озера превышала 18 м. Вход был с северной стороны. Его функции были востребованы вплоть до XVII века. Малое городище было для Торопца тем же, что Кремль и Детинец для других городов. Торопчане, жившие на посаде, имели осадные дворы в городе, то есть здесь, в Малом городище, находили прибежище жители близлежащих мест во время набегов литовцев.

Одним из самых интересных периодов существования города Торопца - это середина XII века, когда город состоял из Детинца и Посада, то есть шло заселение Большого городища. Эта эпоха 
именуется «княжеской», так как тогда (1167) Торопец становится центром практически самостоятельного Торопецкого удельного княжества, составляющего по территории северную треть главного Смоленского, и вскоре становится полностью независимым.

В этот же период идёт интенсивное развитие города и обособление Торопецкого удела. В 1245 году Детинец переместился на посад в Большое городище. Первоначальный город в Большом городище, остатки которого ещё и ныне различимы на юге современного города, занимал территорию в 17 га. С запада он была защищён высокими и крутыми склонами холмов и заливом реки Торопы. С юга были устроены искусственные валы и рвы, о чем свидетельствуют остатки возвышенности и вала. Известно, что внутри него было три церкви. На восточной границе территории построили крепость.

В период с XIV до XVI века Кремль в Торопце формировался на новом месте - городище Красный вал, - относящемся к типу островных укреплений. Форма Кремля была рассчитана на отражение активного штурма с артиллерийской поддержкой. В конце XVII века торопецкий Кремль был мощной крепостью, имел деревянную стену высотой в 20 венцов с девятью башнями. Опытные фортификаторы, такие, например, как И.С. Вахромеев - строитель укреплений Путивля и Орешка, в 1586 году произвёл реконструкцию крепости (рис. 2).

Новый посад возник на правом берегу реки, связанным с Кремлём коротким наплавным мостом, по которому в случае опасности население могло перебраться на остров. Таким образом, в начале XVI века был создан фактически новый город Торопец, и переселение осуществлялось уже на обжитое место.

Историк И.И. Побойнин писал, что в результате пожара и потопа «город» был оставлен, и торопчане переселились на место нынешнего посада, который к середине XIV века был обнесён деревянными стенами. Стены и в конце XV века «подавному строились и охранялись городскими волостными людьми» [5]. Известно, что сам посад существовал с XIV века. Генетическими частями города были: собственно «город», имевший в окружности менее версты и находившийся на острове, окружённом озером Соломено и рекою Торопой.

Из «города», через ворота Московской башни - Никольские, шла дорога по Большому мосту в Торопецкий посад, который уже в первой половине XVI века занимал почти то же пространство, какое занимает он и в настоящее время. Лучшая часть посада «Старый острог» имела в окружности примерно полторы версты (785 сажен). К нему примыкала менее населённая часть посада, в которой находились Стрелецкая, Пушкарская и Посадская слободы; весь посад вместе с находившимися в нём слободами имел в окружности менее трёх вёрст. К посаду с восточной стороны примыкало озеро Соломено, а с южной - река Торопа и Новый посад. К посаду вокруг прирастали слободы: Плавная и Новая (Святицкая), деревни Спасская, Харино, Измино, Подгородняя (Лахоры), Зацкая, Мельничище (Черная Грязь), Горбы, Ивановская (Вторые Горбы) и Городок (Третьи Горбы). На юге вблизи Московской башни находилась Ямская слобода. И даже в XVII веке город Торопец со своими укреплениями, как и в древнюю эпоху, продолжал иметь для волостных людей чрезвычайно важное значение как почти единственное надёжное убежище от врагов [5, с. 84]

В 1651-1653 годы для защиты от неприятельских вторжений был построен новый рубленый острог - так называемый «косой» «ставлен одни концы в тарасы», а другие - «ко рву за тарасы». В нём шесть глухих башен и две - с воротами (Московская и Никольская). Приведённые описания подтверждают, что город «шёл» с юга на север. Этот эволюционный процесс запечатлён в градостроительной структуре, которая несёт в себе характерные черты времени и строительного мастерства.

Ремесленная, торговая и даже сельскохозяйственная деятельность находили отражение и в формах организации территории. Город расширялся слободами, освоенными под хлебопашество, и наделами, где ставились дома. Разнообразие планировочных конфигураций отдельных зон дорегулярного плана свидетельствует о том, что участки различаются по времени освоения и по функциям, по характеру застройки, конфигурации и форме территории в зависимости от расположения в природной среде, её специфических характеристик по отношению к сложившейся системе.

Нельзя не отметить и роль монастырей в формировании и развитии градостроительной структуры. B XVI-XVII веках в городе Торопце и одноимённом уезде было четыре монастыря: два в Торопецком посаде и два в уезде. Мужской Николаевский особный монастырь в древности был расположен на берегу озера Заликовье. После перемещения города на новое место он оказался на окраине Торопецкого посада, внутри окружавших его стен ближе к Московской башне, ворота которой по монастырю назывались Никольскими. Впоследствии монастырская Никольская церковь, где хранилась особо почитаемая икона св. Николая, обрела свой приход и сохранила своё местоположение в градостроительной структуре.

Второй, девичий, монастырь Рождества Иоанна Предтечи существовал в древнем Торопце с 1540 года и находился в посаде на Ивановской улице на том же месте, где находится в настоящее время церковь Иоанна Предтечи. Позже Иоанно-Предтеченская церковь, подобно Никольской, сделалась приходской.

Третьим и четвёртым в ближайшем окружении, хотя и вне пределов города, были монастыри Троицкий в Харитоновой пу-

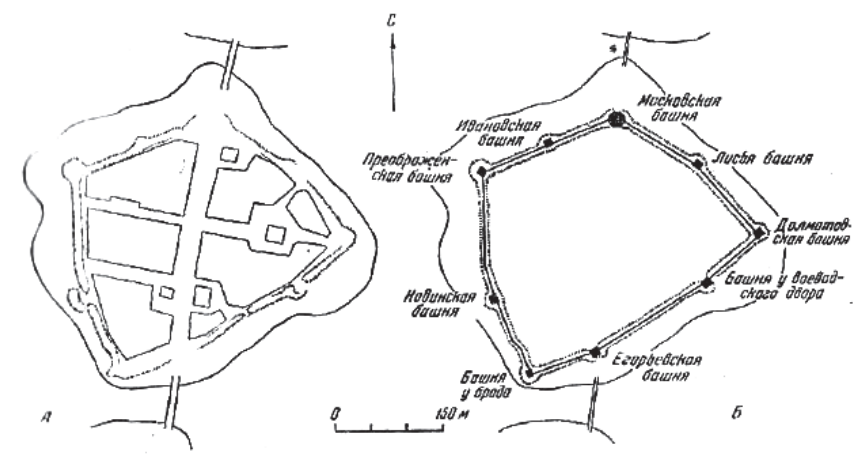

Puс. 2. Торопец. Кремль на Красном острове. Реконструкция И.А. Pannonopma [4, с.13]: а) современное состояние; б) схема оборонный укреплений 
стыни и Небин Троицкий вблизи подгородней деревушки Небино, где жили ямщики. Небин монастырь, был основан в 1592 году.

Троицкий в Харитоновой пустыни монастырь располагался трёх-четырёх верстах от города в Кудине в лесистой местности на берегу реки Торопы, заселённой в XVI веке. Основан он был преподобным Харитоном, в память которого и назывался Харитоновой пустынью. Внегородские монастыри были центрами локальных систем расселения, прирастающих к Торопцу, расширяя тем самым масштабы градостроительной структуры и укрепляя связь города с уездом. Сегодня строения сохранились в полуразрушенном состоянии.

При Небине Троицком монастыре вблизи подгородней деревушки Небино была монастырская слобода с девятью бобыльскими дворами. В 1634 году монастырь сгорел. С 1670 года началось его восстановление. В 1718-ом была построена двухпрестольная пятиглавая каменная церковь св. Троицы с приделом в честь Тихвинской иконы Пресвятой Богородицы. Монастырь в полуразрушенном виде сохранился до наших дней. И по-прежнему Троицкая церковь присутствует и в видовом раскрытии панорамы, и в общей композиции города.

В 1764 году три монастыря были упразднены, и для города и уезда остался только один Небин монастырь. И тем не менее монастыри формировали плоть градостроительной структуры. Один из них - бывший Никольский особный монастырь в 2005 году восстановлен как Свято-Тихоновский в память последнего патриарха Тихона, уроженца Торопца.

В 1897 году жителей в городе насчитывалось 7566 человек. Жилых зданий было 1527, из них каменных - 96. 18 православных каменных церквей: Корсуно-Богородицкий собор, 13 приходских церквей (из них семь самостоятельных и шесть приписных), три кладбищенских церкви. В предместье значился Небин монастырь, основанный в 1592 году, где находился Троицкий собор, который можно считать городским.

В начале XX века в знаменитой крепости Детинце на Красном острове сохранялись ещё вал и деревянная стена в

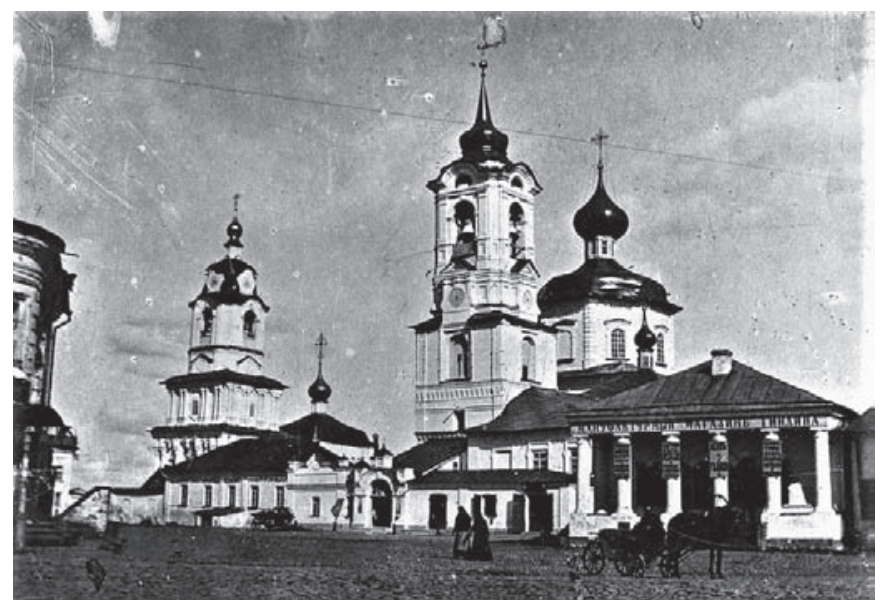

Pис. 3. Торопец. Базарная площадь. Фото начала ХХ века (источник: фонды Торопецкого краеведческого музея ${ }^{1}$ )
22 венца с боями в три яруса. Внутри было два собора, четыре церкви и девять башен. На тот момент ещё сохранялись катки для спуска во время осады.

Обращает на себя внимание устойчивость сформировавшейся композиционной системы. И.И. Побойнин писал, что уже в 1540 году в городе было 16 церквей. Из них в «городе» (то есть на острове) расположен был старинный соборный храм св. Егория, вновь построенный Троицкий собор и церковь св. Афанасия и Кирилла. На посаде продолжал существовать приход с церковью во имя Чудотворца Николая с приделом Покрова Пресвятой Богородицы, сохранившийся на месте древнего мужского Николаевского монастыря, и оставшийся от Рождественского девичьего монастыря храм Рождества Иоанна Предтечи. Помимо монастырских в «Старом остроге» существовали старинные церкви Борисоглебская и Пятницкая. «На торгу» рядом с Пятницкой были построены церкви Воскресения Христова, Архангела Михаила «на исаде» и Ильи Пророка.

Вместе с наращиванием территориальных частей композиционная система развивается путём перемещения на новые места церквей и монастырей, получавших на осваиваемых участках новые отводы земель, мельницы, выгоны, приписанные деревни и слободы. Тогда и сформировалась окончательно пространственно-композиционная система как единый ансамбль и закрепилось отчётливое построение её геометрической основы.

Временная ось истории города начинает отсчёт от Малого Высокого городища, находящегося на въезде в город. Далее исторический путь ведёт к Красному острову, где был Детинец, и наконец, к Старому торгу XVI века - это Воскресенская, или Базарная площадь, сложившаяся как въезд в Посад. Эта площадь - по существу генетическая часть - «древний торг», начало формирования которого относится к XIV веку и во многом сохраняет отпечатки дорегулярной морфологии. Причудливо и свободно рассредоточены по периметру интересные дома XVIII века. Дом Безносова, здание торгового назначения, где сейчас расположен банк «0ткрытие». Дома под номерами 6 и 7 вписаны в периметр площади и одновременно являются началом главной улицы и запоминающимися ориентирами въезда в новый город. Они служат пропилеями перехода в новое пространство - улицы Миллионной. На ней сохранились в почти подлинном виде образцы типовых двухэтажных домов в стиле классицизм середины XVIII века. Фасады их отделаны «бриллиантовым рустом» (дома № 15-17), да и вся улица ансамбль в стиле классицизм.

Местоположение утраченных церквей - слева Архангельская церковь с часами на колокольне, справа - Входоиерусалимская (Пятницкая) - фиксирует территорию, очень ответственную по своей мемориальной и композиционной значимости (рис. 3, 4).

1 Торопецкий краеведческий музей - ГБУ культуры Тверской области «Тверской государственный объединённый музей». 
Дорегулярный план со свободной системой улиц органично закрепил местоположения храмов (рис. 5). Система, открытая и обозреваемая на фоне обширнейших водных территорий, оказалась устойчивой, целостной и образной. Именно она и стала основой перепланировки (рис. 6). Понимая ценность пространственной системы храмов, авторы нового регулярного плана подчинились ей, поддерживая и акцентируя ансамбли храмов площадями. Планировка приспосабливалась к расстановке храмов, господствующих на площадях в едином образно-видовом пространстве (рис. 7, 8, 9).

Архитектурная самобытность храмового зодчества во многом объясняется наличием двух типов храмов: первый тип - одноглавые церкви, в основе которых кубический объём и средневековая архитектурно-художественная стилистика. Церквей такого типа меньше в общем объёме. Среди них Церковь Спаса Преображения и Казанская (конец XVII-XVIII век).

Вторая группа объединяется темой «восьмерик на четверике», который завершается масштабным куполом, увенчанным главкой. В эту группу входили сама Воскресенская церковь и соседствующие с ней Михайло-Архангельская, Входоиерусалимская, а также Благовещенская (утр.), Успенская, Рождественская и Никольская.

Ансамбли объединяются пространственными взаимосвязями, в основе которых прочитываются оси, одна из них идёт от Богоявления к Успенской церкви и Рождества Христова, а в прошлом она проходила и через ансамбль Воскресенской церкви.

Даже при наличии утраченной колокольни мы видим характерную торопецкую прорисовку завершения и в сохранившейся церкви Иоанна Предтечи бывшего Рождественского монастыря (рис. 10).

Обращаясь к геометрической схеме построения композиции на основе регулярного плана 1778 года, обнаруживаем, что центральный луч (юг-север) связывал церкви Воскресения, Благовещенья, Никольскую и Покровскую. 0т Богоявления активно просматриваются и Спасский со-

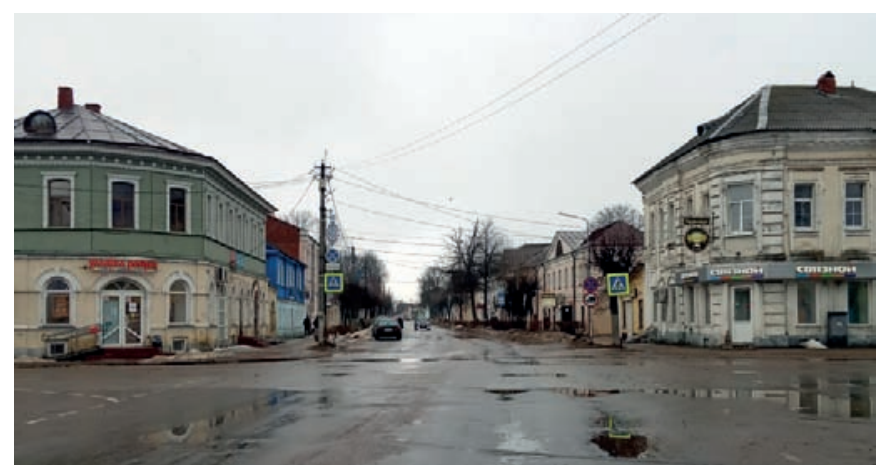

Рис. 4. Tоропец. Исторические здания при въезде на улицу Миллионную (сейчас-улица Советская, дома № 6 и 7). Фото Е.Н. Покрашенко. 2021 год бор, и Казанская церковь, в ближнем восприятии находится Троицкая церковь Небина монастыря. В центральном ядре Посада сосредоточено было девять церквей (Спасский собор, Казанская, Иоанна Предтечи, Благовещенья, Успенская, Воскресенская, Пятницкая, Михаила Архангела и Ильи Пророка). С запада в визуальный обзор встраи-

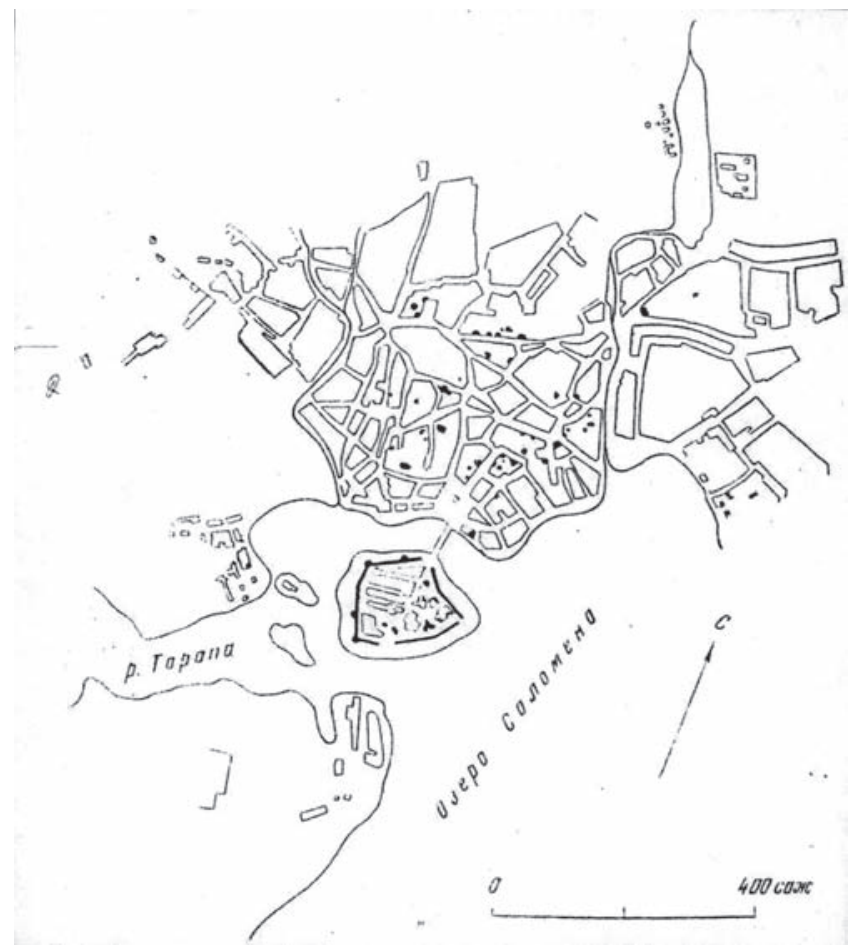

Puc. 5. Toponeu. Дорегулярный план первой половины XVIII века (источник: [4, с. 13])

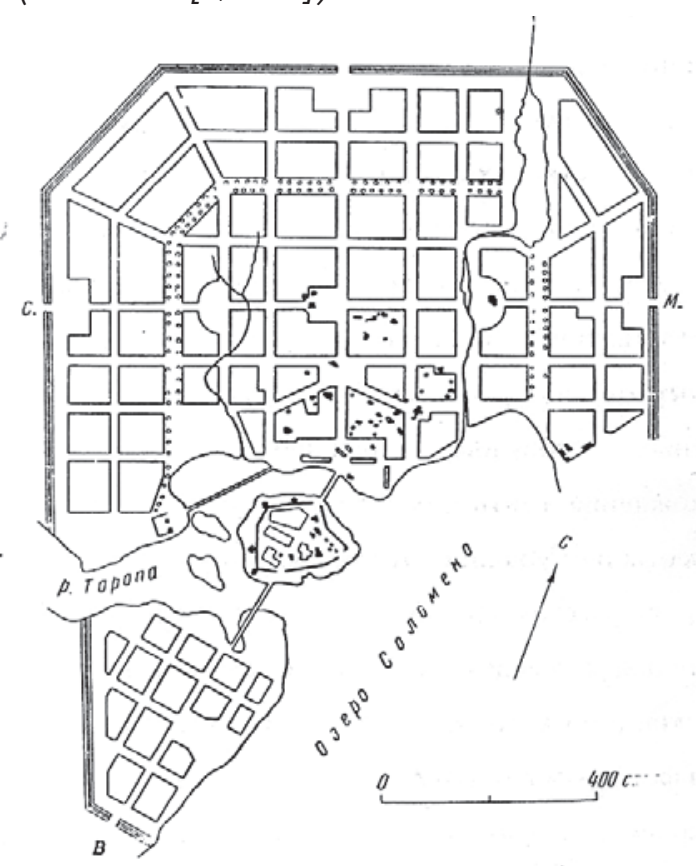

Puс. 6. Торопец. Регулярный план перепланировки 1778 года: В - островная крепость (Кремль); М - Московские ворота; C-Санкт-Петербургские ворота; B-Великолукские ворота (источник: [4]) 
вается Небин монастырь. Южная группа характеризуется линейным расположением вблизи исторического тракта юг-север, начиная от церкви Жён Мироносиц к церквям Корсунской Божьей Матери и к Богоявленской. От неё, в свою очередь - от Спасского собора, и от Небина монастыря - зоны полного визуального обзора всех храмов города (рис. 11).

От Воскресенской раскрывался вид и на церковь Рождества Божьей Матери. Спасо-Преображенский и Иоанно-Пред-

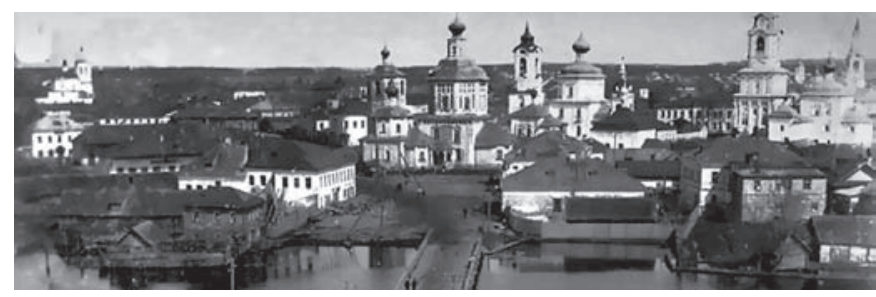

Puс. 7. Торопец. Вид на Воскресенскую (Базарную площадь) с колокольни Богоявленского храма с стороны Красного острова (источник: фонды Торопецкого краеведческого музея)

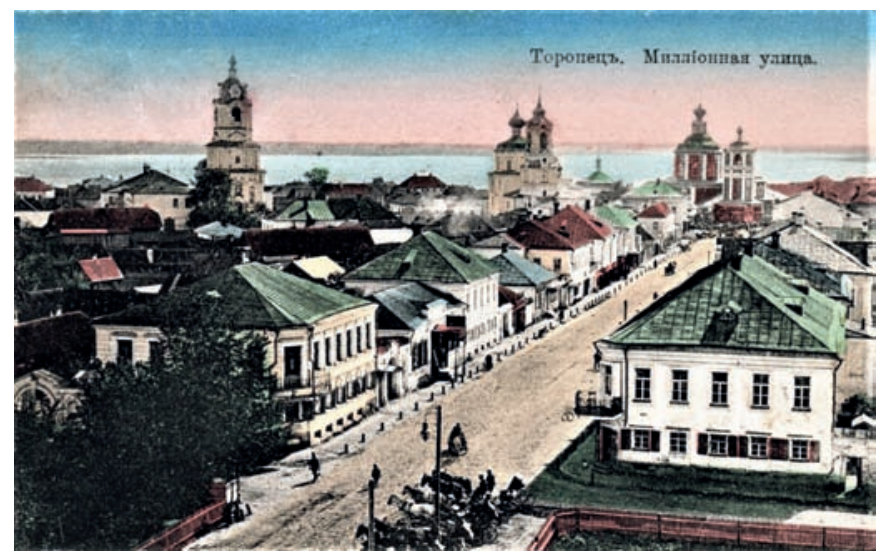

Pис. 8. Торопец. Вид на Советскую (бывш. Миллионную, ещё раньше - Московскую) улицу с колокольни Благовещенской церкви (на дальнем плане четыре храма на Базарной площади (источник: фонды Торопецкого краеведческого музея)

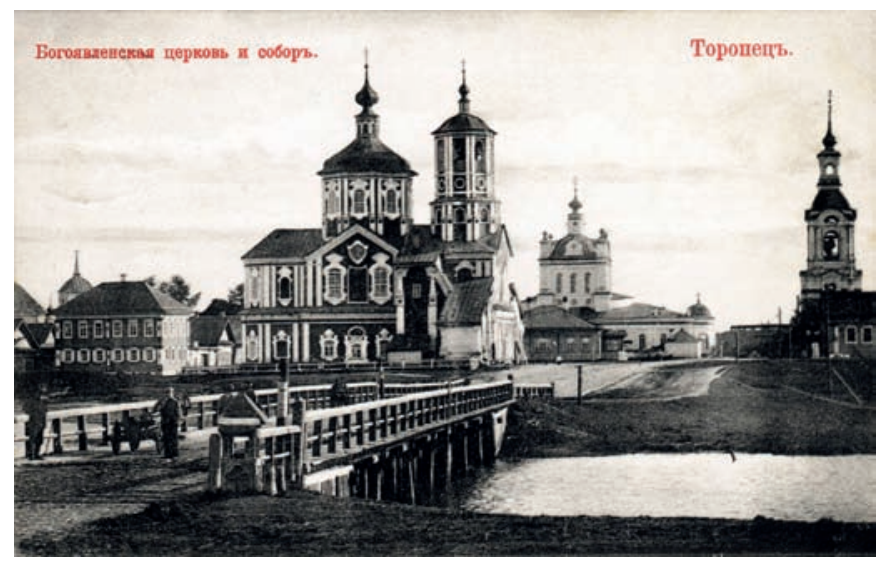

Pис. 9. Богоявленская церковь. Вид от Воскресенской Базарной площади теченский храмы находясь в непосредственной близости к Воскресенской церкви создают её ближайшее окружение.

Покровская церковь (1774-1779) тоже имеет мощный восьмерик, но по своему местоположению она служит развитию широтной оси композиционной системы, по объёму более компактна, центричного плана и не имеет колокольни. Никольская церковь (вторая половина XVII-XVIII век) имеет более заметный купол, перекрывающий восьмерик весьма внушительных размеров. Декор следует древнерусским образцам, присутствуют спаренные арки с висячей гирькой. А.М. Салимов подчёркивал, что церквей типа восьмерик на четверике, выстроенных в конце XVII - начале XVIII веков, имеющих позднесредневековый декор, только две - Воскресенская и Никольская [6].

Началом всей храмовой композиции служит собор Корсунской Божьей Матери, связанный с легендой венчания Александра Невского в бывшей на этом месте древней церкви (рис. см. 2 стр. обл.).

И всё-таки остаётся неразгаданность неповторимого градостроительного своеобразия Торопца, его особой представительности и значительности. Ведь несмотря на все административные переподчинения, присоединения к западным государствам, Торопец оставался верным своим традициям: здесь вырабатывались свои приёмы достижения самобытности и изобретательности в мастерстве архитекторов, и даже появился стиль «торопецкое барокко».

Торопец обладал мощным историко-культурным потенциалом, запечатлённым в яркой архитектуре храмов и застройки, окружавшей город, и имел в прошлом большое значение в становлении и развитии Русского государства:

- являлся опорным центром расселения при освоении территории и контролировал важнейшие трансконтинентальные торговые водные пути (из «варяг в греки»);

- имел с 1167 года и до середины XIV века административный статус столицы Торопецкого удельного княжества с весьма значительной зоной влияния;

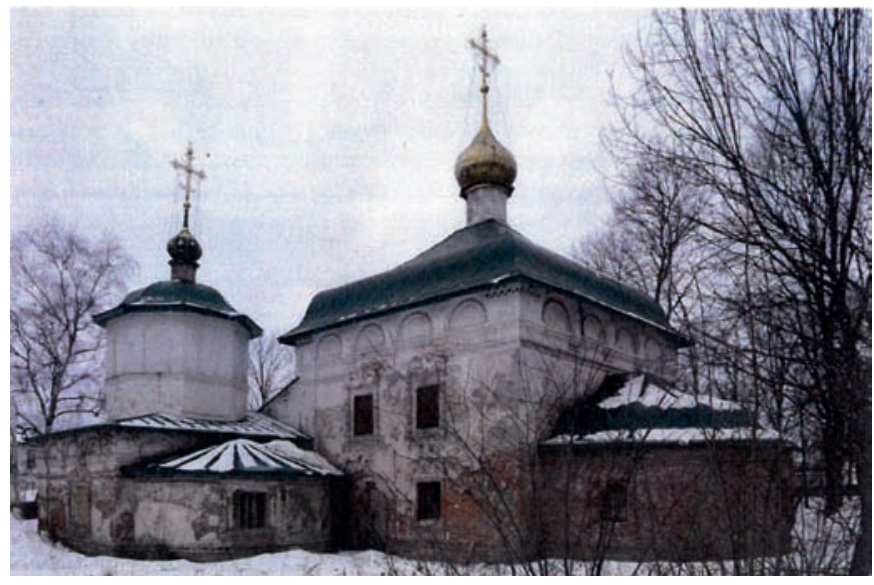

Puc. 10. Торопец. Церковь Иоанна Предтечи. Конец XVIIXVIII век. Вид с юго-востока (источник: личный архив Л.И. Медведевой) 
- был родовой вотчиной Александра Невского, в битвах за которую проявился его военный подвиг как полководца;

- был выбран Александром Невским как место венчания;

- город-крепость - самоотверженно стоял на страже русских земель особенно в эпоху польско-литовской интервенции.
Не случайно роль защитника и стража русских земель отражена и в символике герба. На нём изображён боевой щит, на его зелёном поле сторожевая башня с флагштоком и лук над ней. Автором является Франциск Санти, приглашённый Петром I и создавший 97 гербов.

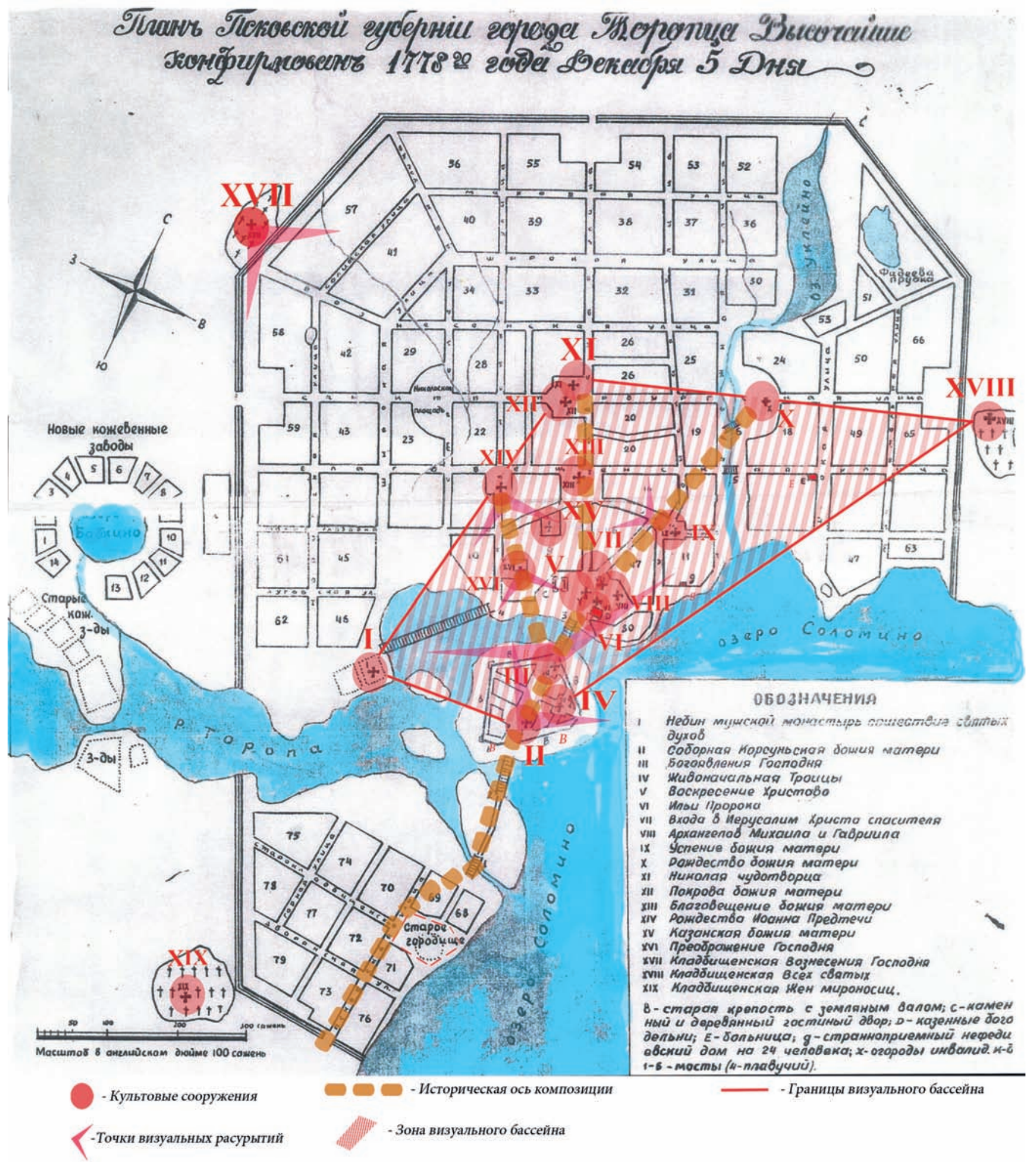

Рис. 11. Геометрическая основа построения композиционно-пространственной системы и визуального пространства активных взаимосвязей ансамблей. Выполнена на «Плане Псковской губернии города Торопца, высочайше конфирмованном 1778 года Декабря 5-го дня». Авторские аналитические построения (источник плана - Торопецкая районная библиотека) 
Исторический потенциал просматривается и в пространственных параметрах, представительности застройки, в архитектурно-художественном мастерстве зодчих, в достоинствах и великолепии храмовой архитектуры, масштабности и опосредованно предстаёт в облике города.

Исторический ход развития территориальных образований с юга на север происходил благодаря внутренним закономерностям (генетическому коду) и сопровождался перемещением в том же направлении и храмовой пространственно-композиционной системы И.И. Побойнин пишет, что в древнем Торопце, называвшемся в XVI-XVII веках Старым Посадом, было четыре церкви: Егорьевская, Борисоглебская, Пятницкая и Рождества Иоанна Предтечи. Главной и древнейшей из них была церковь во имя страстотерпца Георгия (Егорьевский храм).

BXVI веке после Егорьевского собора наиболее значительной была, судя по количеству земли, принадлежавшей ей на Старом посаде (полторы десятины), Борисоглебская церковь.

Отдавая и приписывая земли церквям, территория города в буквальном смысле продвигалась на север.

Многоликий облик города обусловлен временными этапами. В период XV-XVI веков его облик определялся оборонительными функциями и сооружениями. Островной Кремль был архитектурно-композиционным центром Торопца. Шатровые башни, соединяясь с завершениями церквей, доминировали над одноэтажной застройкой. Величественные и стройные объёмы Кремля создавали цельный архитектурный организм, воспринимаемый вместе с многочисленными строениями, свободно разбросанными по берегам озера Соломено, реки Торопы и её притоков. В своём описании, касающемся роли и облика деревянного Кремля в градостроительной структуре XV-XVI веков, В.В. Косточкин подчёркивает, что за рекой на месте нового посада не было «какой-либо определённой планировки», но имеющиеся к тому времени приходские церкви и слободы, то есть свободно разбросанные сооружения, обладали градоформирующим характером. И в описании будущего Посада присутствует термин «свободная планировка».

Дорегулярная основа территории складывалась в соответствии с топографией местности. Именно тогда были заложены основы пространственной системы. Именно в дорегулярной планировке определены были местоположения храмов и внутренняя связность с градостроительной структурой. Как говорит Ю.И. Курбатов, они лишь были угаданы авторами последующего регулярного плана. Закреплению этой связи содействовали новые площади - Рождественская, Благовещенская, которые обеспечивали пространственную взаимосвязь храмов.

В 1778 году после пожара город получил новый план, согласно которому осуществлялась перепланировка. В нём учитывалось расположение храмов, и он был адаптирован к сложившейся системе. Нельзя не учесть, что Воскресенская площадь с развитым храмовым ансамблем являлась сохранившейся генетической древней частью - торгом. Она определила разбивку главной оси вдоль Большой (Миллионной) улицы, ориентированной на Благовещенскую площадь. Её конфигурация удерживает дорегулярную планировку и морфологию. Её роль, главного въезда в новую часть города, генетическая достоверность и целостность обусловлена природными условиями (южная часть площади омывается рекой Торопой) и характером эволюции. Город рос частями, разделенными водными пространствами. Площадь - торг - имела относительно обособленное местоположение. Он сложился еще в XIV веке, когда сгорел Детинец.

Уникальное явление - сохранившийся торг, важная генетическая часть в традиционной структуре русского города: остаётся неизменным град-посад с торгом посредине. Пространство его было открытым как к водным просторам озера, так и к городскому окружению. Не случайно торг в виде развитой площади был акцентирован мощным ансамблем из четырёх церквей с колокольнями, что служило кульминацией планировки всего города

Такая поступательная и последовательная форма продвижения города с юга на север сформировала осевое построение композиции от первого по пути Георгиевского храма Корсунской Божьей Матери (бывш. Георгиевский). Следующий акцент - Богоявленская церковь, от которой открывается весь Новый посад, и она считается частью ансамбля Воскресенской церкви, поскольку была ближайшей к церквям на Воскресенской площади.

Расположение церквей композиционно организует градостроительную структуру. Их местоположение определили контур пространственно-композиционного пространства, в пределах которого воспринимаются храмовые доминанты и присутствуют визуальные связи между ними.

Естественно появившееся и стихийно сформировавшееся осевое построение композиционной системы закреплено Корсунской, Богоявленской, Воскресенской и далее Успенской и Рождественской церквями.

Поскольку Воскресенская церковь сконцентрировала вблизи себя ансамбль в виде четырёх церквей, она стала фокусом, от которого возник новый луч вдоль Большой (Советской) улицы, ориентированный на Благовещенскую церковь. Это мастерски прочли авторы нового регулярного плана в дорегулярной планировке и закрепили в послепожарном регулярном плане. Более того, и Рождественская, и Благовещенская стали композиционными доминантами площадей. Следующие лучи связали Воскресенскую с Казанским и Спасо-Преображенским храмами. Такая градостроительная структура и сохранилась до наших дней. При этом сосуществованию дорегулярных начал, вписанных в градостроительную структуру, ничто не мешает. ИоанноПредтеченская церковь, сохранившаяся с XVI века, имеет глубинное расположение. Вне этих лучей остались Казанская церковь и Спасо-Преображенский собор.

Дорегулярная конфигурация Воскресенской и Базарной площадей оказалась устойчивой и благодаря этому сохра- 
нилась открытость общегородской композиции в единстве с Красным островом.

Естественной основой самостоятельно сложившейся оси стала сама дорога. Вдоль неё были расположены церкви: Корсунская, Богоявления и Воскресения, далее - к церкви Рождества. И этот луч времени, который и сейчас читается в структуре, идёт от первой церкви Корсунской Божьей Матери вплоть до церкви Всех Святых у самой границы города. Да и весь город - чудо! «В моём представлении ни один российский город не сравнится с красотой с Торопцом. Красота эта не парадная и не кукольная», - так определил славу Торопца В.М. Воробьев, профессор государственной Академии славянской культуры (Тверь). Это отчётливо видно на гравюрах К.Вейермана (рис. 13, 15).

И в самом деле, в гравюре просматривается образ кремля, контуры которого закрепляются расположением церквей (на востоке видна Успенская церковь, на западе - Троицкая церковь Небина монастыря). Здесь же уместно подчеркнуть весьма заметную роль восьмериков в панорамном образе.

Главное организующее значение в построении композиционной системы города и Воскресенской площади принадлежит Воскресенской церкви. Она была возведена в центре площади, на пересечении оси в створе моста через реку Торопу и другой оси - вдоль Миллионной (Советской) улицы. Её колокольня соразмерна по высоте с главным

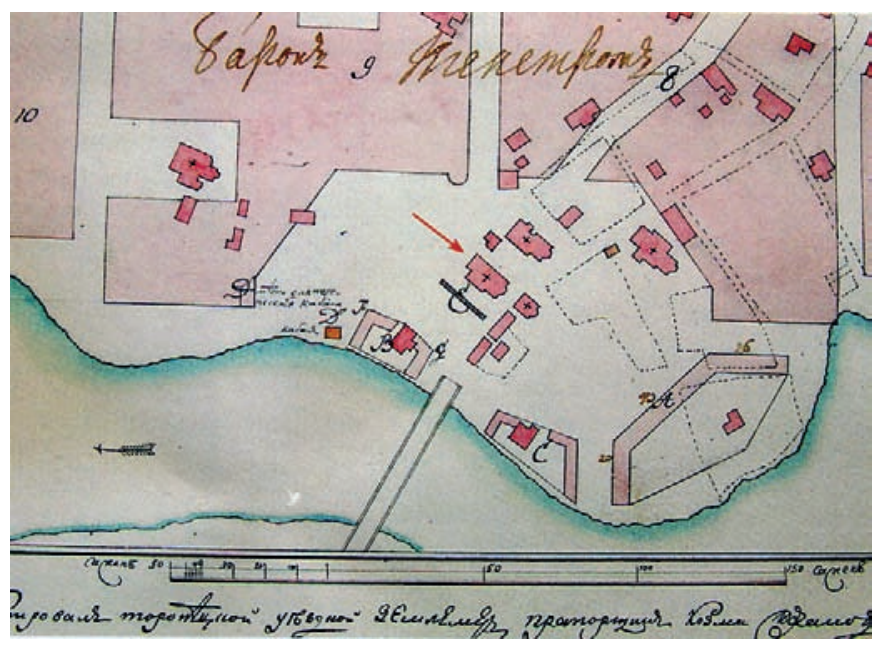

Puc. 12. Торопец. Воскресенская площадь на плане 1790-х годов (источник: ГАПО. Ф.74. On.1. Д.327. А 110 [95])

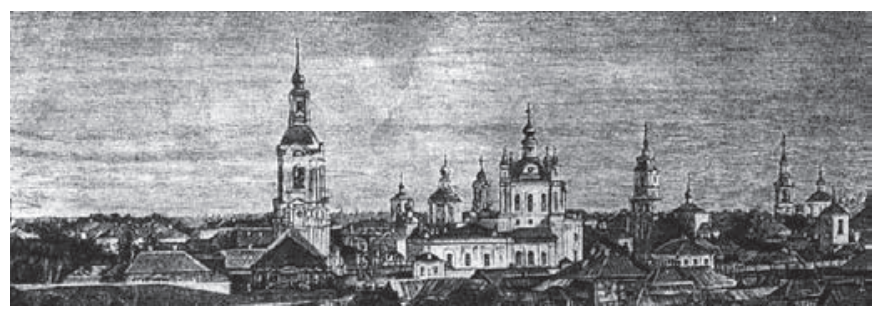

Puc. 13. Tоропец. Панорама города в середине XIX века. В центре Корсунско-Богородицкий собор Гравюра К. Вейермана [7, c. 204] объёмом и не превышает её по высоте. При этом она имеет самый внушительный по размерам восьмерик в центральном объёме. Севернее расположена Входоиерусалимская церковь, созвучная по масштабу и формам, которая гармонично развивает объёмную композицию. Повторяется восьмерик и в прорисовке её купольного завершения. Несколько поодаль, на втором плане, с юга можно видеть восьмерики Входоиерусалимской и Ильинской церквей. Тема восьмериков получает причудливую трактовку благодаря разнообразию соотношений высоты, ширины, сосуществующих в соседстве друг с другом. Та же общая тема завершающих куполов, зрительно воспринимающихся вместе. Даже прослеживается сходство завершений восьмериков Успенской и Входоиерусалимской церквей. Всё это храмовое единство - развитая объёмная композиция - представляет собой целостность, в которую выходит ранее сложившаяся система: от Георгиевского храма к Богоявленскому. Следует подчеркнуть, что ближайшей к ансамблю Базарной площади является Богоявленская, в которой также господствуют восьмерики, встроенные в общем объёме симметрично. Это смелый приём русской трактовки западноевропейских образцов. Устремлённые в небеса колокольни Входоиерусалимской церкви созвучны, близки по решению духу европейского барокко.

Воскресенская церковь имеет особую художественную и эстетическую специфику. Здесь и спаренные арки с вися-

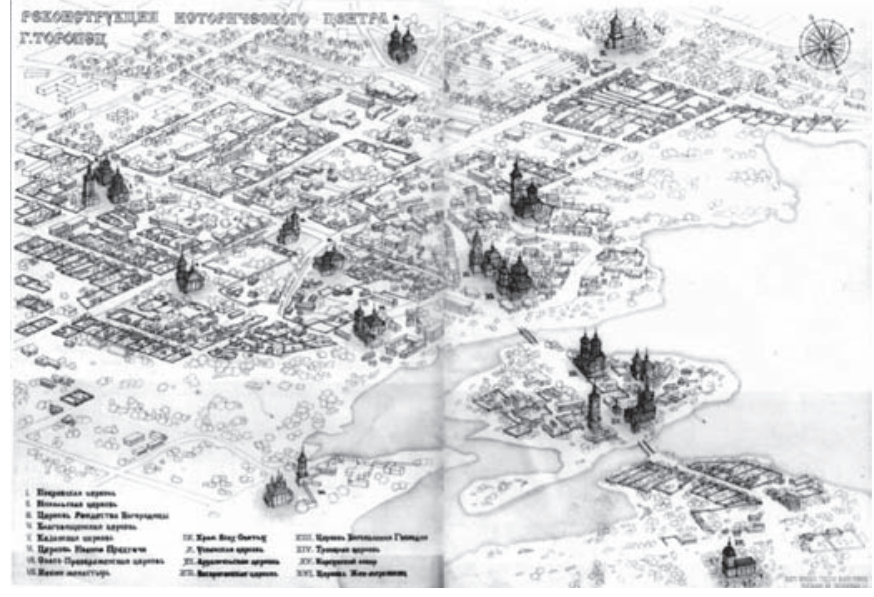

Puc. 14. Торопец. Пространственно-композиционная система, включающая утраченные церкви (выполнено студентами МАРХИ [8])

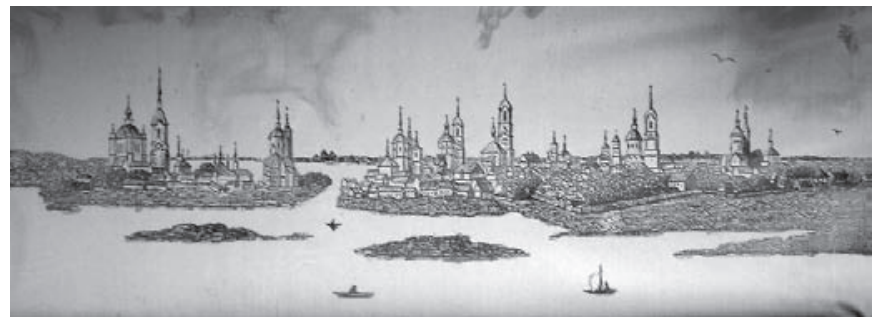

Puc. 15. Toponеu. Панорама города в середине XIX века. Гравюра К. Вейермана по рисунку Адамова (источник: [2]) 
чей гирькой, здесь и изразцы в подкарнизном ряду. Очень изобретательно решены наличники. И в прорисовке купола заметно западное влияние.

На рисунке 14 видно группы церквей, относящиеся к генетическим частям: Красному острову, Торгу и Посаду.

Обращаясь к плану, можно увидеть и начало композиционной оси: на юге Георгиевский собор Корсунской Божьей Матери, далее Богоявленский в Кремле на Красном острове и Воскресенская церковь, вблизи которой сформировался ещё в дорегулярном плане центральный ансамбль, мастерски вписанные в регулярный план. От Богоявленской церкви полностью видна храмовая система Посада.

Также с Посада видно раскрытие храмовых доминант. Бесспорно, что в расположении храмов присутствует система. Именно поэтому они и просматриваются активно в их взаимосвязях. Картина города, поражала всех, представляя собой «сияющие купола разноцветных массивных каменных церквей, слепившихся в одну кучу». Вот что писал историк XIX века В. Щукин - настоятель Корсунско-Богородицкого собора города Торопца: «При озере Соломено, реке Торопе расположен небольшой уездный городок Торопец со своими 19 церквами, которые, будучи расположенными вблизи друг от друга, придают ему довольно оригинальный вид, вид какого-то Кремля» [2]. Он определил истинную идею единого ансамбля города как композиционного созвучия церквей (рис. 15).

Сравнивая гравюру К. Вейермана с современным состоянием, мы видим сохранность градостроительной структуры и основу построения композиционной системы в целом. Они порождают те же «эстетические эмоции», о которых говорил Хосе Луис Борхес, и духовно востребованы всеми и во все времена как потребность в идентичности и истинных ценностях [9-11]. Несмотря на утрату церквей, композиция уцелела и дарит нам эстетические эмоции от встречи с прекрасным. Город Торопец обладает мощным историческим потенциалом и культурным наследием, не изучены многие грани его самобытных градостроительных традиций и строительного мастерства. 0 них пойдет речь в последующих публикациях.

\section{Лuтература}

1. Иродионов, П.И. Исторические, географические и политические сведения для города Торопца и его округа касающиеся / П.И. Иродионов. - СПб, 1778; Репринт. - Тверь : Седьмая буква, 2010. - 32 с.

2. Нефёдова, Л.Г. Торопец: прошлое и настоящее : Сборник очерков / Л.Г. Нефёдова. - Нелидово : Верхневолжская ассоциация периодической печати, 1996. - 78 с. - С. 9-10.

3. Покрашенко, Е.Н. Экскурс : Рукопись / Е.Н. Покрашенко // Личный архив Е.Н. Покрашенко. - Торопец.

4. Косточкин, B.В. Архитектурные памятники Торопца / В.В. Косточкин // Памятники культуры. Исследование и реставрация. - М., 1959. - 95 с.

5. Побойнин, И.И. Торопецкая старина. Исторические очерки города Торопца с древнейших времён до конца XVII века / И.И. Побойнин; отв.ред. В.М. Воробьев; Изд.3-е. Тверь : Седьмая буква, 2009. - 348 с.

6. Салимов, А.М. Храмовая архитектура Торопца XVII-XVIII веков / А.М. Салимов. - Тверь : Салимовы и Ко, 2019. - 80 с.

7. Русское градостроительное искусство. Москва и сложившиеся русские города XVIII - первой половины XIX веков / под ред. Н.Ф Гуляницкого. - М. : Стройиздат, 1998. - 449 с.

8. Федулова, 0.Ю. Рисунки русской архитектуры : учебные работы студентов МАРХИ. Опыт преподавания / 0.Ю. Федулова, М.Г. Романова. - М. : МАРХИ, 2015.

9. Борхес, Х.-Л. Девять эссе о Данте / пер. с исп. А. Фридмана // Мир Данте : в 3-х томах. Т.3. - М. : ТЕРPA, 2002. - С. 243-264.

10. Есаулов, Г.В. Об идентичности в архитектуре и градостроительстве / Г.В. Есаулов // Academia. Архитектура и строительство. - 2018. - № 4. - С. 12-18.

11. Крамаровский, М.Г. Человек средневековой улицы. Золотая Орда, Византия, Италия / М.Г. Крамаровский. - Спб : Евразия, 2012. - 296 с.

12. Щенков, А.С. Привычное и программное в охране наследия / А.С. Щенков // Academia. Архитектура и строительство. - 2015. - № 1. - С. 39-40.

\section{References}

1. Irodionov P.I. Istoricheskie, geograficheskie i politicheskie svedeniya dlya goroda Toroptsa i ego okruga kasayushchiesya [Historical, geographical and political information for the city of Toropets and its districts concerning]. Toropets, 2001, $132 \mathrm{p}$.

2. Nefedova L.G. Toropets: proshloe i nastoyashchee : Sbornik ocherkov [Toropets: Past and Present: Collection of Essays]. Nelidovo, Upper Volga Association of the periodical press Publ., 1996, 78 p. (In Russ.)

3. Pokrashenko E.N. Ekskurs : Rukopis'. Muzeinyi arkhiv [Excursion: Manuscript. Museum archive]. Toropets. (In Russ.)

4. Kostochkin V.V. Arkhitekturnye pamyatniki Toroptsa [Architectural monuments of Toropets]. In: Pamyatniki kul'tury. Issledovanie i restavratsiya [Cultural Monuments. Research and restoration]. Moscow, 1959, 95 p. (In Russ.)

5. Poboinin I.I. Toropetskaya starina. Istoricheskie ocherki goroda Toroptsa s drevneishikh vremen do kontsa XVII veka [Toropetskaya antiquity. Historical sketches of the city of Toropets from ancient times to the end of the 17th century], V.M. Vorob'ev (ed.). Tver', Sed'maya bukva Publ., 2009, 348 p. (In Russ.)

6. Salimov A.M. Khramovaya arkhitektura Toroptsa XVIIXVIII vekov [Temple architecture of Toropets XVII-XVIII centuries]. Tver', Salimovy i Ko Publ., 2019, 80 p. (In Russ.)

7. Gulyanitskii N.F. (ed.) Russkoe gradostroitel'noe iskusstvo. Moskva i slozhivshiesya russkie goroda XVIII - pervoi poloviny XIX vekov [Russian urban planning art. Moscow and the established Russian cities of the 18th - first half of the 19th centuries]. Moscow, Stroiizdat Publ., 1998, 449 p. (In Russ.)

8. Fedulova 0.Yu., Romanova M.G. Risunki russkoi arkhitektury : uchebnye raboty studentov MARKHI. Opyt 
prepodavaniya [Drawings of Russian architecture: educational work of students of the Moscow Architectural Institute. Teaching experience]. Moscow, MARKHI, 2015. (In Russ.)

9. Borkhes Kh.-L. Devyat' esse o Dante [Nine essays about Dante], per. s isp. A. Fridman (trans.). In: Mir Dante [Dante's World], in 3 vol. Vol. 3. Moscow, TERRA Publ., 2002, pp. 243-264. (In Russ.)

10. Esaulov G.V. Ob identichnosti $v$ arkhitekture $i$ gradostroitel'stve [0n identity in architecture and urban planning]. In: Academia. Arkhitektura i stroitel'stvo [Academia.
Architecture and construction], 2018, no. 4, pp. 12-18. (In Russ., abstr.in Engl.)

11. Kramarovskii M.G. Chelovek srednevekovoi ulitsy. Zolotaya Orda, Vizantiya, Italiya [Medieval street man. Golden Horde, Byzantium, Italy]. St. Petersburg, Evraziya Publ., 2012, 296 p. (In Russ.)

12. Shchenkov A.S. Privychnoe i programmnoe v okhrane naslediya [Habitual and programmatic in heritage protection]. In: Academia.Arkhitektura i stroitel'stvo [Academia. Architecture and construction], 2015, no. 1, pp. 39-40. (In Russ., abstr.in Engl.)

Кубецкая Любовь Ивановна (Москва). Старший научный сотрудник ЦнИИП Минстроя России (проспект Вернадского, 29. цНИИП Минстроя России. E-mail: kubeckayal@mail.ru.

Кудрявцева Наталия Орестовна (Москва). Ph.D. Архитектор. E-mail: designbyaspect@yahoo.uk.com.

Kubetskaya, Lyubov I. (Moscow). Senior Researcher at Institute for Research and Design of the Ministry of Construction and Housing and Communal Services of Russia (29 Vernadskogo avenue, Moscow, 119331. TsNIIP). E-mail: kubeckayal@mail.ru.

Kudryavtseva, Natalia 0. (Moscow).Ph.D. Architect.E-mail: designbyaspect@yahoo.uk.com. 